Editor's Note: These short reviews of recent JNeurosci articles, written exclusively by students or postdoctoral fellows, summarize the important findings of the paper and provide additional insight and commentary. If the authors of the highlighted article have written a response to the Journal Club, the response can be found by viewing the Journal Club at www.jneurosci.org. For more information on the format, review process, and purpose of Journal Club articles, please see http://jneurosci.org/content/ preparing-manuscript\#journalclub.

\title{
$\beta$-Catenin Pathway Is Involved in TREM2-Mediated Microglial Survival
}

\author{
Shadaan Zulfiqar and Gaye Tanriöver \\ Institute for Pharmacology and Clinical Pharmacy, Philipps University, Marburg 45043, Germany \\ Review of Zheng et al.
}

Amyloid plaques and neurofibrillary tangles are prominent lesions that are commonly found in the brains of Alzheimer's disease $(\mathrm{AD})$ patients. Hence, faulty amyloid processing, deposition, and clearance have been postulated as the central event in disease pathogenesis, which along with abnormal tau hyperphosphorylation leads to synaptic and neuronal loss (Hardy and Selkoe, 2002). Although neuroinflammation has been associated with plaques and tangles (Rogers et al., 1992; Duong et al., 1997), it was considered a passive process that arose in the terminal stages of AD. However, the last few years have seen a resurgence of interest in the role of neuroinflammation in AD. This is partly due to a series of genetic studies that identified microglial immune receptors, such as TREM2, CD33, and CR1 as risk factors (Lambert et al., 2009; Naj et al., 2011; Guerreiro et al., 2013a; Jonsson et al., 2013).

TREM2 is an innate immune receptor and a Type I transmembrane protein. TREM2 mediates signaling through the phosphorylation of the ITAM motif of its partnering adaptor protein DNAX-

Received April 22, 2017; revised June 9, 2017; accepted June 16, 2017.

We thank Junior Prof. Dr. Katja Nieweg and Dr. Saikat Ray for invaluable comments in preparation of the manuscript.

The authors declare no competing financial interests.

Correspondence should be addressed to Shadaan Zulfiqar, Institute for

Pharmacology and Clinical Pharmacy, Karl von Frisch Strasse 1, Marburg 45043, Germany. E-mail: shadaan.zulfiqar@pharmazie.uni-marburg.de.

DOI:10.1523/JNEUROSCI.1087-17.2017

Copyright $\odot 2017$ the authors $\quad 0270-6474 / 17 / 377073-03 \$ 15.00 / 0$ activating protein of $12 \mathrm{kDa}$ (DAP12) (Bouchon et al., 2001). This further recruits the tyrosine kinase Syk, which activates downstream targets. In the CNS, it is expressed exclusively in microglia, and it has mainly been shown to be involved in phagocytosis (Xiang et al., 2016), promoting microglial survival (Otero et al., 2009), and in regulating inflammation in the CNS. A loss-of-function mutation in the TREM2 gene gives rise to Nasu-Hakola disease, which manifests as dementia and bone cysts. Furthermore, recent genomewide association studies have shown that an arginine to histidine $(\mathrm{R} 47 \mathrm{H})$ coding variant in TREM2 triples the AD risk of the carrier, having an effect size comparable with that of the well-established late-onset $\mathrm{AD}$ risk gene, APOE4 (Neumann and Daly, 2013; Guerreiro et al., 2013b). The R47H mutation has also been found to be associated with frontotemporal dementia, amyotrophic lateral sclerosis, and Parkinson's disease (Cady et al., 2014; Rayaprolu et al., 2013). Although this mutation is rare and found in $<1 \%$ of the population, the study of TREM2 offers new insights into the role of neuroinflammation in $\mathrm{AD}$ and could lead to developing potential novel therapeutics.

The role of TREM 2 in imparting vulnerability to $\mathrm{AD}$, and its key downstream players are yet to be thoroughly investigated. Thus, in a recent study published in The Journal of Neuroscience, Zheng et al. (2017) investigated the molecular path- ways underlying TREM2-mediated proliferation and survival of microglia. Using microglia derived from TREM2 knockout $(\mathrm{KO})$ mice, the authors demonstrated a reduction in microglial cell proliferation as well as survival. TUNEL staining indicated that a larger percentage of microglia were apoptotic in $\mathrm{KO}$ mice than in wildtype (WT), and this was confirmed by the increase in proapoptotic cleaved Caspase-3 and reduction of antiapoptotic protein Bcl-2. Notably, proliferation and survival were also reduced in primary microglia from WT mice after TREM2 was knocked down using siRNAs targeting different domains. The two siRNAs reduced TREM2 mRNA levels by $\sim 50$ and $70 \%$, respectively, thus possibly simulating a heterozygous phenotype. These findings dovetailed with those of Wang et al. (2015), who also observed that microglia from TREM2-deficient animals were more likely to undergo apoptosis.

Using intraperitoneal injection of kainic acid to induce glutamate excitotoxicity in WT and TREM2 KO mice, Zheng et al. (2017) studied TREM2-dependent microglial activation in vivo. Using Ibal as a microglial marker, they observed a marked difference between $\mathrm{KO}$ and WT in the number and morphology of microglia in both cortical and hippocampal regions. Specifically, WT microglia were more numerous, had greater area, and had shorter processes than TREM2-deficient microglia. These results suggest that 
knocking out TREM2 reduced microglial activation.

After demonstrating TREM2 involvement in cell proliferation and apoptosis, Zheng et al. (2017) investigated the role of TREM2 in cell cycle progression and control. TREM2 $\mathrm{KO}$ resulted in an increased percentage of microglia in the $G_{1} / G_{0}$ phase compared with WT microglial cells. Further confirming this finding, levels of Cyclin D1 (a protein essential for progression through $\mathrm{G}_{1}$ phase) and c-Myc (a direct regulator of cell cycle machinery) were reduced in TREM2 $\mathrm{KO}$ microglia.

Because $\beta$-catenin initiates transcriptional activation of cyclin D1 and c-Myc, Zheng et al. (2017) hypothesized that this protein might be a downstream effector of TREM2. First, they asked whether TREM2 regulates $\beta$-catenin transcription by measuring mRNA content. They found no difference between the WT and KO cells. Therefore, they asked whether TREM2 regulates proteasomal degradation of $\beta$-catenin by measuring protein levels in the presence of a protein synthesis inhibitor. $\beta$-Catenin protein levels showed a faster reduction over time in the $\mathrm{KO}$ cells, suggesting that TREM2 suppresses the proteasomal degradation of $\beta$-catenin. This was further confirmed by treatment of the KO cells with a proteasomal inhibitor, MG132, which rescued the degradation effect.

Under canonical Wnt signaling, $\beta$-catenin accumulates in the cytoplasm before eventually translocating to the nucleus, but in the absence of Wnt, $\beta$-catenin is targeted for proteasomal degradation by GSK3 $\beta$ (Clevers and Nusse, 2012). GSK3 $\beta$ can, in turn, be inactivated upon phosphorylation by activated AKT. To investigate how TREM2 might stabilize $\beta$-catenin, Zheng et al. (2017) measured the phosphorylation status of Akt and GSK3 $\beta$. Phosphorylation levels of Akt and GSK3 $\beta$ were significantly lower in TREM2 knockdown and $\mathrm{KO}$ microglia than in controls, confirming the role of Akt/Gsk3 $\beta$ pathway activation in TREM2-mediated $\beta$-catenin stabilization.

Next, Zheng et al. (2017) asked whether stabilizing $\beta$-catenin would rescue the effects of TREM2 loss. Indeed, activating the canonical Wnt signaling pathway with Wnt3a treatment partially restored microglial survival and proliferation of TREM2 KO microglia. In addition, the GSK3 $\beta$ inhibitor lithium chloride $(\mathrm{LiCl})$ inhibited Gsk $3 \beta$-induced $\beta$-catenin degradation, increased $\beta$-catenin levels, and moderately increased microglia viability in vitro. These results were replicated in vivo by $\mathrm{LiCl}$ treatment, although the rescue of
c-Myc and cyclin D1 levels was partial, suggesting that this is not the sole pathway through which TREM2 influences microglial survival and proliferation.

In summary, Zheng et al. (2017) demonstrated that TREM2 mediates its effects on microglial proliferation through a $\beta$-catenin pathway. These findings are in agreement with recent studies showing that TREM2-DAP12, upon activation by macrophage colony stimulating factor, promotes macrophage survival in a $\beta$-catenindependent manner (Otero et al., 2009). These results also align with another study showing that soluble TREM2 (sTREM2), arising from proteolytic cleavage of TREM2, may complement TREM2 activity of enhancing microglial survival and suppressing apoptosis, in a PI3K-Akt-dependent manner (Zhong et al., 2017). Additionally, studies using TREM2-deficient mice have confirmed poor activation of microglia (Kawabori et al., 2015).

Observations from Zheng et al. (2017), along with other studies, thus hint at a possible mechanism by which TREM2 mutation imparts vulnerability to $\mathrm{AD}$. Amyloid deposition is an important pathological hallmark in $\mathrm{AD}$, and previous studies have suggested that TREM2 aids in compacting amyloid plaques (Yuan et al., 2016). A loss-of-function mutation in TREM2 would result in decreased surviving and dividing microglia as well as an increased area occupied by plaques. This would expose more neurons to amyloid plaques, which might result in greater dystrophy. Components of damaged and dead neurons, such as sphingolipids and nucleic acids (Kawabori et al., 2015; Wang et al., 2015), serve as potential ligands to TREM2, but as Zheng et al. (2017) suggest, a loss-offunction mutation would compromise microglial activation. Furthermore, TREM2deficient animals have been shown to have impaired phagocytosis and clearance (Kawabori et al., 2015), leading to more uncleared cell debris. These events may put the system in a vicious neurotoxic cycle.

Zheng et al. (2017) provide a therapeutic direction of enhancing $\mathrm{Wnt} / \beta$-catenin signaling to push microglia to a healthier state. Indeed, converging lines of evidence suggest that the Wnt pathway is dysregulated in $\mathrm{AD}$, and Wnt3a and $\mathrm{LiCl}$ have been used to rescue $\beta$-amyloid-induced neurodegeneration in rats (De Ferrari et al., 2003). However, Wnt3a stimulation has also been shown to exacerbate the proinflammatory immune response of microglia (Halleskog et al., 2011). Although this could be beneficial in early stages, aiding in clearing amyloid and de- bris; with aging and disease progression, chronic activation of microglia could be counterproductive, leading to neurotoxicity. Hence, a proper titration of dosage to tightly regulate the immune response is important.

In conclusion, Zheng et al. (2017) have reported new insights into TREM2-mediated microglial survival and identified $\beta$-catenin as an important role player in TREM2initiated signaling pathways. Therefore, it offers the promise of developing effective therapeutics to overcome microglial dysfunction in neurodegeneration.

\section{References}

Bouchon A, Hernández-Munain C, Cella M, Colonna M (2001) A DAP12-mediated pathway regulates expression of CC Chemokine Receptor 7 and maturation of human dendritic cells. J Exp Med 194:1111-1122. CrossRef Medline

Cady J, Koval ED, Benitez BA, Zaidman C, JockelBalsarotti J, Allred P, Baloh RH, Ravits J, Simpson E, Appel SH, Pestronk A, Goate AM, Miller TM, Cruchaga C, Harms MB (2014) TREM2 variant $\mathrm{p} . \mathrm{R} 47 \mathrm{H}$ as a risk factor for sporadic amyotrophic lateral sclerosis. JAMA Neurol 71:449-453. CrossRef Medline

Clevers H, Nusse R (2012) Wnt/ $\beta$-catenin signaling and disease. Cell 149:1192-1205. CrossRef Medline

De Ferrari GV, Chacón MA, Barría MI, Garrido JL, Godoy JA, Olivares G, Reyes AE, Alvarez A, Bronfman M, Inestrosa NC (2003) Activation of Wnt signaling rescues neurodegeneration and behavioral impairments induced by $\beta$-amyloid fibrils. Mol Psychiatry 8:195-208. CrossRef Medline

Duong T, Nikolaeva M, Acton PJ (1997) C-reactive protein-like immunoreactivity in the neurofibrillary tangles of Alzheimer's disease. Brain Res 749:152-156. CrossRef Medline

Guerreiro R, Lohmann E, Brás JM, Gibbs JR, Rohrer JD, Gurunlian N, Dursun B, Bilgic B, Hanagasi H, Gurvit H, Emre M, Singleton A, Hardy J (2013a) Using exome sequencing to reveal mutations in TREM2 presenting as a frontotemporal dementia-like syndrome without bone involvement. JAMA Neurol 70:78-84. CrossRef Medline

Guerreiro R, Wojtas A, Bras J, Carrasquillo M, Rogaeva E, Majounie E, Cruchaga C, Sassi C, Kauwe JS, Younkin S, Hazrati L, Collinge J, Pocock J, Lashley T, Williams J, Lambert JC, Amouyel P, Goate A, Rademakers R, Morgan $\mathrm{K}$, et al. (2013b) TREM2 variants in Alzheimer's disease. N Engl J Med 368:117-127. CrossRef Medline

Halleskog C, Mulder J, Dahlström J, Mackie K, Hortobágyi T, Tanila H, Kumar Puli L, Färber K, Harkany T, Schulte G (2011) WNT signaling in activated microglia is proinflammatory. Glia 59:119-131. CrossRef Medline

Hardy J, Selkoe DJ (2002) The amyloid hypothesis of Alzheimer's disease: progress and problems on the road to therapeutics. Science 297: 353-356. CrossRef Medline

Jonsson T, Stefansson H, Steinberg S, Jonsdottir I, Jonsson PV, Snaedal J, Bjornsson S, Hutten- 
locher J, Levey AI, Lah JJ, Rujescu D, Hampel H, Giegling I, Andreassen OA, Engedal K, Ulstein I, Djurovic S, Ibrahim-Verbaas C, Hofman A, Ikram MA, et al. (2013) Variant of TREM2 associated with the risk of Alzheimer's disease. N Engl J Med 368:107-116. CrossRef Medline

Kawabori M, Kacimi R, Kauppinen T, Calosing C, Kim JY, Hsieh CL, Nakamura MC, Yenari MA (2015) Triggering receptor expressed on myeloid cells 2 (TREM2) deficiency attenuates phagocytic activities of microglia and exacerbates ischemic damage in experimental stroke. J Neurosci 35:3384-3396. CrossRef Medline

Lambert JC, Heath S, Even G, Campion D, Sleegers K, Hiltunen M, Combarros O, Zelenika D, Bullido MJ, Tavernier B, Letenneur L, Bettens K, Berr C, Pasquier F, Fiévet N, Barberger-Gateau P, Engelborghs S, De Deyn P, Mateo I, Franck A, et al. (2009) Genomewide association study identifies variants at CLU and CR1 associated with Alzheimer's disease. Nat Genet 41:1088-1093. CrossRef Medline

Naj AC, Jun G, Beecham GW, Wang LS, Vardarajan BN, Buros J, Gallins PJ, Buxbaum JD, Jarvik GP, Crane PK, Larson EB, Bird TD, Boeve BF, Graff-Radford NR, De Jager PL, Evans D, Schneider JA, Carrasquillo MM, ErtekinTaner N, Younkin SG, et al. (2011) Common variants at MS4A4/MS4A6E, CD2AP, CD33 and EPHA1 are associated with late- onset Alzheimer's disease. Nat Genet 43:436441. CrossRef Medline

Neumann H, Daly MJ (2013) Variant TREM2 as risk factor for Alzheimer's disease. N Engl J Med 368:182-184. CrossRef Medline

Otero K, Turnbull IR, Poliani PL, Vermi W, Cerutti E, Aoshi T, Tassi I, Takai T, Stanley SL, Miller M, Shaw AS, Colonna M (2009) Macrophage colony-stimulating factor induces the proliferation and survival of macrophages via a pathway involving DAP12 and betacatenin. Nat Immunol 10:734-743. CrossRef Medline

Rayaprolu S, Mullen B, Baker M, Lynch T, Finger E, Ross OA, Seeley WW, Hatanpaa KJ, Lomen-Hoerth C, Kertesz A, Bigio EH, Lippa C, Josephs KA, Knopman DS, White CL 3rd, Caselli R, Mackenzie IR, Miller BL, BoczarskaJedynak M, Opala G, Krygowska-Wajs A, et al. (2013) TREM2 in neurodegeneration: evidence for association of the p.R47H variant with frontotemporal dementia and Parkinson's disease. Mol Neurodegener 8:19. CrossRef Medline

Rogers J, Cooper NR, Webster S, Schultz J, McGeer PL, Styren SD, Civin WH, Brachova L, Bradt B, Ward P (1992) Complement activation by $\beta$-amyloid in Alzheimer disease. Proc Natl Acad Sci U S A 89:10016-10020. CrossRef Medline

Wang Y, Cella M, Mallinson K, Ulrich JD, Young
KL, Robinette ML, Gilfillan S, Krishnan GM, Sudhakar S, Zinselmeyer BH, Holtzman DM, Cirrito JR, Colonna M (2015) TREM2 lipid sensing sustains the microglial response in an Alzheimer's disease model. Cell 160:10611071. CrossRef Medline

Xiang X, Werner G, Bohrmann B, Liesz A, Mazaheri F, Capell A, Feederle R, Knuesel I, Kleinberger G, Haass C (2016) TREM2 deficiency reduces the efficacy of immunotherapeutic amyloid clearance. EMBO Mol Med 8:9921004. CrossRef Medline

Yuan P, Condello C, Keene CD, Wang Y, Bird TD, Paul SM, Luo W, Colonna M, Baddeley D, Grutzendler J (2016) TREM2 haplodeficiency in mice and humans impairs the microglia barrier function leading to decreased amyloid compaction and severe axonal dystrophy. Neuron 90:724-739. CrossRef Medline

Zheng H, Jia L, Liu CC, Li Zhong ZR, Yang L, Chen XF, Fryer JD, Wang X, Zhang YW, Xu H, Bu G (2017) TREM2 promotes microglial survival by activating $\mathrm{Wnt} / \beta$-catenin pathway. J Neurosci 37:1772-1784.

Zhong L, Chen XF, Wang T, Wang Z, Liao C, Wang Z, Huang R, Wang D, Li X, Wu L, Jia L, Zheng H, Painter M, Atagi Y, Liu CC, Zhang YW, Fryer JD, Xu H, Bu G (2017) Soluble TREM2 induces inflammatory responses and enhances microglial survival. J Exp Med 214: 597-607. CrossRef Medline 